Supporting Information for

\title{
One-pot/Sequential Native Chemical Ligation Using Photocaged Crypto-thioester
}

Keisuke Aihara, Kosuke Yamaoka, Naoto Naruse, Tsubasa Inokuma, Akira Shigenaga and Akira Otaka*

Institute of Biomedical Sciences and Graduate School of Pharmaceutical Sciences, Tokushima University, 1-78-1 Shomachi, Tokushima 770-8505, Japan

E-mail:

aotaka@ tokushima-u.ac.jp

Contents

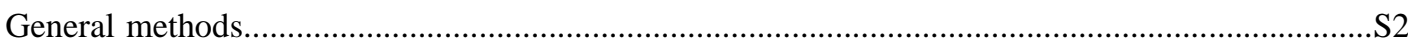

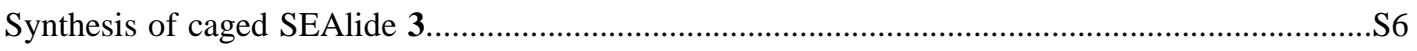

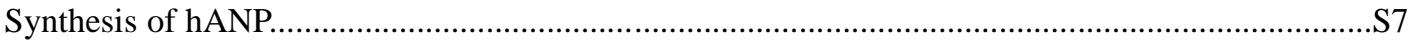

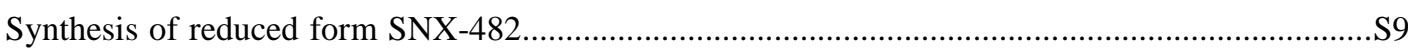

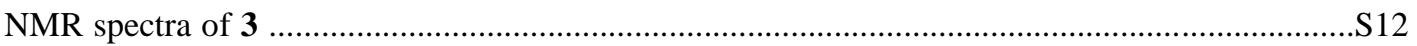

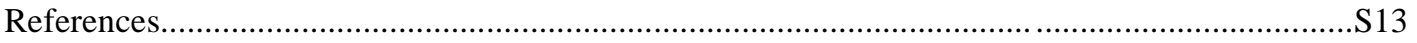




\section{General Methods}

NMR spectra were recorded using a Bruker AV400N at $400 \mathrm{MHz}$ frequency for ${ }^{1} \mathrm{H}$, and JEOL JNM-AL300 at $75 \mathrm{MHz}$ frequency for ${ }^{13} \mathrm{C}$. Mass spectra were recorded on a Waters MICROMASS ${ }^{\circledR}$ LCT PREMIERTM (ESI-TOF). For HPLC separations, a Cosmosil 5C 18 -AR-II analytical column (Nacalai Tesque, $4.6 \times 250 \mathrm{~mm}$, flow rate $1.0 \mathrm{~mL} / \mathrm{min}$ ), a Cosmosil Protein-R analytical column (Nacalai Tesque, $4.6 \times 250 \mathrm{~mm}$, flow rate $1.0 \mathrm{~mL} / \mathrm{min}$ ), a TSKgel Octadecyl-2PW analytical column (TOSOH CORPORATION, $4.6 \times 150 \mathrm{~mm}$, flow rate $1.0 \mathrm{~mL} / \mathrm{min}$ ), a Cosmosil 5C 18 -AR-II semi-preparative column (Nacalai Tesque, $10 \times 250 \mathrm{~mm}$, flow rate $3.0 \mathrm{~mL} / \mathrm{min}$ ) and a Cosmosil $5 \mathrm{C}_{18}$-AR-II preparative column (Nacalai Tesque, $20 \times 250 \mathrm{~mm}$, flow rate $10.0 \mathrm{~mL} / \mathrm{min}$ ) were employed, and eluting products were detected by UV at $220 \mathrm{~nm}$. A solvent system consisting of $0.1 \%$ (v/v) TFA aqueous solution (solvent A) and $0.1 \%$ (v/v) TFA in MeCN (solvent B) was used for HPLC elution. VILBER LOURMAT VL-30L (wavelength: $365 \mathrm{~nm}, 2 \times 15 \mathrm{~W}$, power: $60 \mathrm{~W}$ ) was used for UV irradiation.

\section{Fmoc solid-phase peptide synthesis (SPPS)}

Peptides 6, 7, 13, 14, 15 and 21 were synthesized manually on a NovaSyn ${ }^{\circledR}$ TGR resin $(0.25$ mmol amine/g). Peptides $\mathbf{8}$ and $\mathbf{1 6}$ were synthesized manually on a Wang resins on which Fmoc-Tyr $\left({ }^{t} \mathrm{Bu}\right)-\mathrm{OH}$ $\left(0.44 \mathrm{mmol}\right.$ amine/g) or Fmoc-Asp $\left(\mathrm{O}^{t} \mathrm{Bu}\right)-\mathrm{OH}(0.68 \mathrm{mmol}$ amine/g) was preloaded, respectively. Fmoc solid-phase peptide synthesis was performed according to the following protocol.

1. Removal of Fmoc groups were performed with $20 \%$ (v/v) piperidine in DMF for 10 min at room temperature.

2. The resin was washed with DMF.

3. An Fmoc-protected amino acid (Fmoc-Xaa-OH) (5.0 eq.) was coupled with the resin in the presence of $\mathrm{N}, \mathrm{N}$-diisopropylcarbodiimide (DIPCDI) (5.0 eq.) and 1-hydroxy-1H-benzotriazole monohydrate $\left(\mathrm{HOBt} \cdot \mathrm{H}_{2} \mathrm{O}\right.$ ) (5.5 eq.) in DMF for $1.5 \mathrm{~h}$ at room temperature. Completion of the coupling reaction was checked by the Kaiser ninhydrin test. When a result of the Kaiser test had been positive, the second coupling employing a mixture of Fmoc-Xaa-OH (3.0 equiv), $N, N$-diisopropylethylamine

(DIPEA) (3.0 equiv) and $\quad N, N, N^{\prime}, N^{\prime}$-tetramethyl- $O$-(1H-benzotriazol-1-yl)uronium hexafluorophosphate (HBTU) (2.9 equiv) in DMF at room temperature for $1 \mathrm{~h}$ was performed.

4. The resin was washed with DMF.

5. A cycle of step 1 to 4 was repeated.

Deprotection of acid-labile protecting groups with concomitant release of peptides from a resin was achieved using a cocktail of TFA $/ m$-cresol/thioanisole/1,2-ethanedithiol $/ \mathrm{H}_{2} \mathrm{O}$ (90:2.5:2.5:2.5:2.5 (v/v), 50 
$\mu \mathrm{L} / 1 \mathrm{mg}$ resin) at room temperature for $1.5 \mathrm{~h}$. After the resin was filtered off, cooled diethyl ether $\left(\mathrm{Et}_{2} \mathrm{O}\right)$ was added and the precipitate was collected by centrifugation. The obtained precipitate was washed with cooled $\mathrm{Et}_{2} \mathrm{O}$, purified by semi-preparative or preparative HPLC. Characterization data of peptides are listed in Table S1.

\section{Removal of 6-nitroveratryl (NV) or 6-nitroveratryloxycarbonyl (NVOC) group.}

Before removal of the NV or NVOC group, thiophenol $(\mathrm{PhSH})$ in the reaction mixture was extracted with $\mathrm{Et}_{2} \mathrm{O}$. The obtained aqueous solution was then flushed with argon, sealed and placed in photoreactor. UV irradiation was performed at $365 \mathrm{~nm}$ for up to $3 \mathrm{~h}$ and the obtained reaction mixture which contains an uncaged peptide was subjected to the following native chemical ligation. 


\section{Scheme S1. Synthesis of peptide 16.}

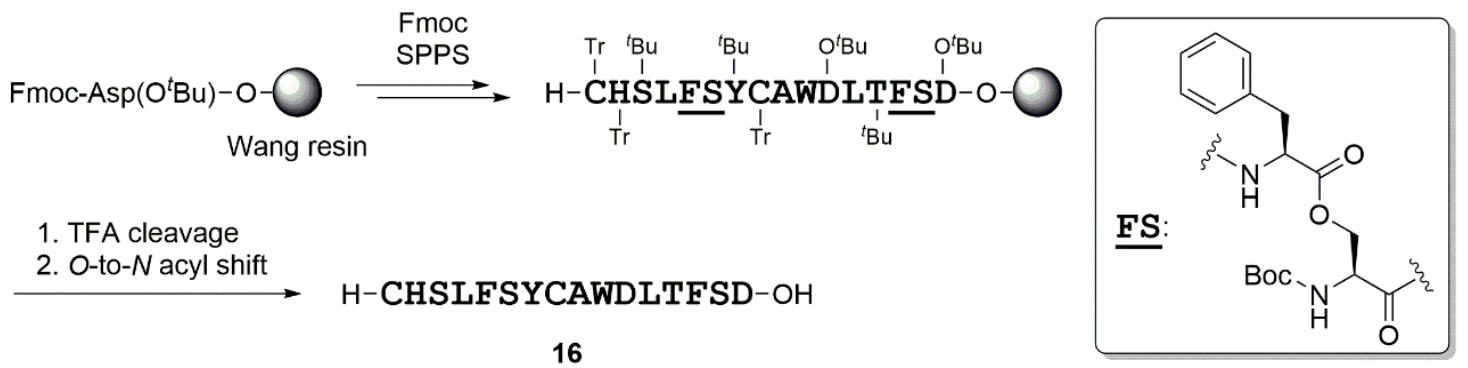

For the preparation of $\mathbf{1 6}, O$-acyl isopeptide method ${ }^{\mathrm{S} 1}$ was employed. A peptide chain containing $O$-acyl building units was elongated according to the literature, and the completed resin was treated with TFA cocktail according to the general method. After the resin was filtered off, cooled diethyl ether $\left(\mathrm{Et}_{2} \mathrm{O}\right)$ was added and the precipitate was collected by centrifugation. The obtained precipitate was washed with cooled $\mathrm{Et}_{2} \mathrm{O}$. A solution containing this isopeptide in $6 \mathrm{M}$ guanidine hydrochloride $(\mathrm{Gn} \cdot \mathrm{HCl})-0.2 \mathrm{M}$ sodium phosphate buffer $(\mathrm{NaPB})(\mathrm{pH}=7.0)$ was incubated at $37^{\circ} \mathrm{C}$ for $1 \mathrm{~h}$, and the solution was purified by preparative HPLC to give linear peptide 16. Characterization data of the peptide are listed in Table S1.

\section{Preparation of peptide 21.}

\section{Scheme S2. Synthesis of peptide 21.}
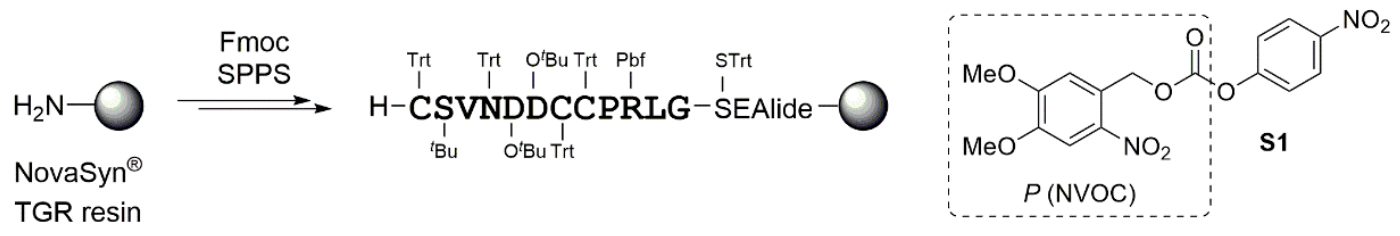

1. Nvoc protection

2. TFA cleavage

$P$-CSVNDDCCPRLG-SEAlide- $\mathrm{NH}_{2}$

21

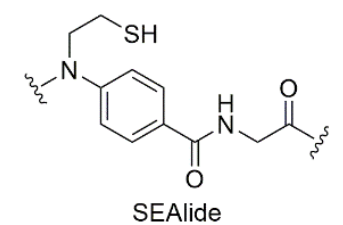

SEAlide

After the construction of a peptide chain, this resin was treated with $\mathbf{S 1}^{\mathrm{S} 2}$ (3.0 eq.) and DIPEA (4.0 eq.) in DMF at room temperature for $4 \mathrm{~h}$. The obtained N-terminal protected resin was globally deprotected according to the general method and a HPLC purification afforded NVOC-protected peptide 21. Characterization data of peptide $\mathbf{2 1}$ are listed in Table S1. 
Table S1. Characterization data of peptide fragments.

\begin{tabular}{|c|c|c|c|c|c|c|c|}
\hline \multirow{2}{*}{ Peptide } & \multicolumn{2}{|c|}{ Analytical HPLC ${ }^{1}$} & \multicolumn{2}{|c|}{ Preparative HPLC ${ }^{2}$} & \multicolumn{2}{|l|}{$m / z$} & \multirow{2}{*}{$\begin{array}{l}\text { Yield } \\
(\%)\end{array}$} \\
\hline & Retention time (min) & Gradient (\%) & Column & Gradient $(\%)$ & Calcd & Found & \\
\hline 6 & 15.4 & $1-50$ & A & $7-22$ & $940.5[\mathrm{M}+\mathrm{H}]^{+}$ & 940.3 & 6 \\
\hline 7 & 18.0 & $10-60$ & A & $21-36$ & $1028.0[\mathrm{M}+2 \mathrm{H}]^{2+}$ & 1028.1 & 31 \\
\hline 8 & 17.4 & $1-50$ & A & $13-25$ & $395.4[\mathrm{M}+2 \mathrm{H}]^{2+}$ & 395.3 & 19 \\
\hline 13 & 9.5 & $10-55$ & A & $5-20$ & $391.2[\mathrm{M}+2 \mathrm{H}]^{2+}$ & 391.3 & 22 \\
\hline 14 & 22.2 & $10-55$ & A & $25-38$ & $632.2[\mathrm{M}+2 \mathrm{H}]^{2+}$ & 632.2 & 8 \\
\hline 15 & 21.0 & $10-55$ & A & $22-35$ & $856.3[\mathrm{M}+2 \mathrm{H}]^{2+}$ & 856.1 & 36 \\
\hline 16 & 23.9 & $10-55$ & B & $30-45$ & $947.9[\mathrm{M}+2 \mathrm{H}]^{2+}$ & 947.6 & 8 \\
\hline 21 & 23.3 & $10-55$ & A & $29-42$ & $878.3[\mathrm{M}+2 \mathrm{H}]^{2+}$ & 878.0 & 11 \\
\hline
\end{tabular}

${ }^{1}$ Cosmosil 5C 18 -AR-II analytical column was employed. ${ }^{2} \mathrm{~A}$ : Cosmosil $5 \mathrm{C}_{18}$-AR-II preparative column was employed.

B: Cosmosil 5C 18 -AR-II semi-preparative column was employed. 


\section{Synthesis of caged SEAlide 3}

\section{Scheme S3. Synthesis of caged SEAlide 3.}

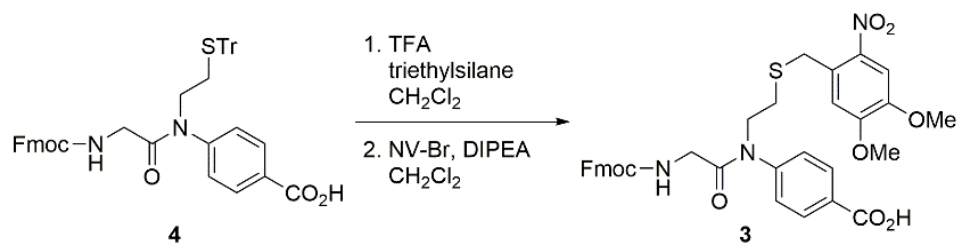

To a solution of $4(100 \mathrm{mg}, 0.139 \mathrm{mmol})$ in $\mathrm{CH}_{2} \mathrm{Cl}_{2}(1.50 \mathrm{~mL})$ at $0{ }^{\circ} \mathrm{C}$ were added triethylsilane $(32.8 \mu \mathrm{L}$, $0.209 \mathrm{mmol})$ and TFA $(2.00 \mathrm{~mL})$, and the reaction mixture was stirred at room temperature for $2 \mathrm{~h}$. After the reaction mixture was evaporated, the residue was diluted with $\mathrm{CH}_{2} \mathrm{Cl}_{2}(1.39 \mathrm{~mL})$. To the resulting solution were added DIPEA (118 $\mu \mathrm{L}, 0.695 \mathrm{mmol})$ and 6-nitroveratryl bromide (NV-Br) (58.0 mg, 0.209 $\mathrm{mmol})$ at $0{ }^{\circ} \mathrm{C}$. After being stirred at room temperature for $1 \mathrm{~h}$, the reaction was quenched with $5 \%(\mathrm{w} / \mathrm{v})$ $\mathrm{KHSO}_{4}$ aq. The solution was extracted with $\mathrm{CH}_{2} \mathrm{Cl}_{2}$, and the obtained organic phase was washed with $5 \%$ (w/v) $\mathrm{KHSO}_{4}$ aq followed by brine, dried over $\mathrm{Na}_{2} \mathrm{SO}_{4}$, filtered and concentrated in vacuo. The residue was purified by column chromatography $\left(\mathrm{CHCl}_{3} / \mathrm{MeOH}=100 / 1-10 / 1(\mathrm{v} / \mathrm{v})\right)$ to yield $3(62.7 \mathrm{mg}, 93.3$ $\mu \mathrm{mol}, 67 \%)$ as a yellow amorphous powder: ${ }^{1} \mathrm{H} \mathrm{NMR}\left(\mathrm{CDCl}_{3}, 400 \mathrm{MHz}\right) \delta=2.64(2 \mathrm{H}, \mathrm{t}, J=7.4 \mathrm{~Hz}), 3.78$ $(2 \mathrm{H}, \mathrm{br} \mathrm{s}), 3.91-3.95(2 \mathrm{H}, \mathrm{m}), 3.94(3 \mathrm{H}, \mathrm{s}), 3.97(3 \mathrm{H}, \mathrm{s}), 4.13(2 \mathrm{H}, \mathrm{s}), 4.20(1 \mathrm{H}, \mathrm{t}, J=7.2 \mathrm{~Hz}), 4.37(2 \mathrm{H}, \mathrm{d}, J=$ $7.2 \mathrm{~Hz}), 5.75(1 \mathrm{H}, \mathrm{br} \mathrm{t}, J=4.0 \mathrm{~Hz}), 6.94(1 \mathrm{H}, \mathrm{s}), 7.29-7.32(4 \mathrm{H}, \mathrm{m}), 7.39(2 \mathrm{H}, \mathrm{t}, J=7.3 \mathrm{~Hz}), 7.58(2 \mathrm{H}, \mathrm{d}, J=$ $7.6 \mathrm{~Hz}), 7.62(1 \mathrm{H}, \mathrm{s}), 7.76(2 \mathrm{H}, \mathrm{d}, J=7.3 \mathrm{~Hz}), 8.10(2 \mathrm{H}, \mathrm{d}, J=8.4 \mathrm{~Hz}) ;{ }^{13} \mathrm{C} \mathrm{NMR}\left(\mathrm{CDCl}_{3}, 75 \mathrm{MHz}\right) \delta=29.3$, 33.9, 43.6, 47.2, 49.1, 56.5, 56.6, 67.6, 108.8, 113.7, 120.1, 125.2, 127.2, 127.9, 128.3, 129.1, 130.4, 132.2, $140.7,141.4,143.8,144.3,148.1,153.1,156.7,168.2,168.5$; HRMS (ESI-TOF) $m / z$ calcd for $\mathrm{C}_{35} \mathrm{H}_{33} \mathrm{~N}_{3} \mathrm{O}_{9} \mathrm{SNa}$ $\left([\mathrm{M}+\mathrm{Na}]^{+}\right): 694.1835$, found: 694.1826 . 
Scheme S4. Synthetic flow chart for the synthesis of hANP.

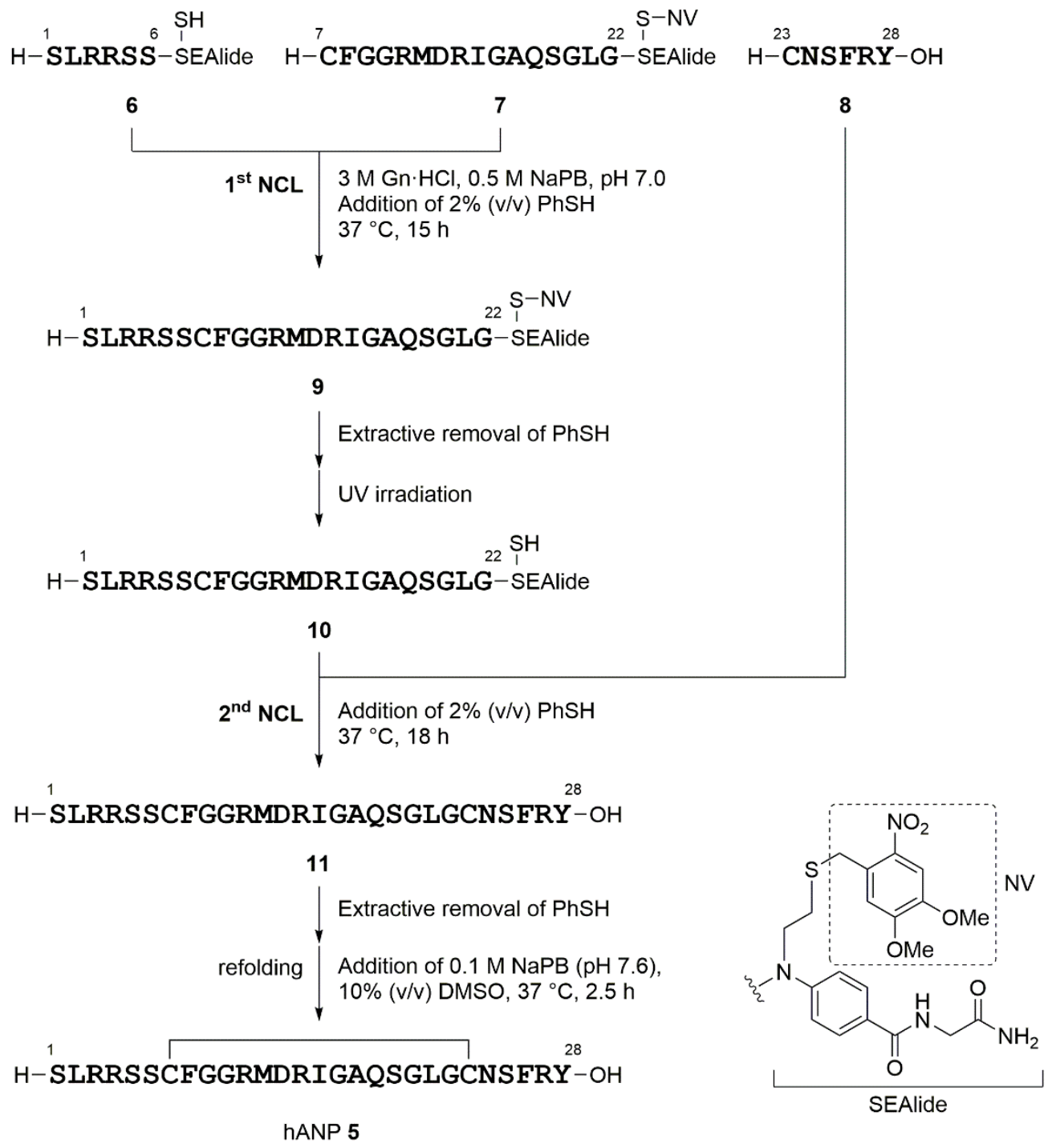

To a mixture of N-terminal fragment $6(1.40 \mathrm{mg}, 1.00 \mu \mathrm{mol})$ and middle fragment 7 (2.51 mg, $1.00 \mu \mathrm{mol})$ in $3 \mathrm{M} \mathrm{Gn} \cdot \mathrm{HCl}-0.5 \mathrm{M} \mathrm{NaPB}(\mathrm{pH} 7.0,1.00 \mathrm{~mL})$ was added 2\% (v/v) $\mathrm{PhSH}$ and the solution was incubated at $37^{\circ} \mathrm{C}$. The reaction was completed within $15 \mathrm{~h}$, and a NV group on ligated product 9 was then cleaved according to the general method to give 10. To this reaction mixture, $2 \%(\mathrm{v} / \mathrm{v}) \mathrm{PhSH}$ and C-terminal fragment 8 were added and the obtained mixture was incubated at $37^{\circ} \mathrm{C}$. After $18 \mathrm{~h}$, the reaction was completed to afford reduced form hANP 11. The reaction mixture was diluted with $0.1 \mathrm{M}$ $\mathrm{NaPB}(\mathrm{pH} 7.6,4.00 \mathrm{~mL})$ and DMSO $(500 \mu \mathrm{L})$, and the mixture was incubated at $37^{\circ} \mathrm{C}$ for $2.5 \mathrm{~h}$. After completion of the oxidative folding, crude materials were purified by semi-preparative HPLC (Cosmosil 
$5 \mathrm{C}_{18}$-AR-II semi-preparative column with a linear gradient of solvent $\mathrm{B}$ in solvent A over 30 min: 20 $35 \%)$ to yield 5 as a white lyophilized powder $(0.97 \mathrm{mg}, 0.26 \mu \mathrm{mol}, 26 \%)$. Characterization data of peptides are shown in Table S2.

Table S2. Characterization data of peptides for the synthesis of hANP.

\begin{tabular}{ccccc}
\hline \multirow{2}{*}{ Peptide } & \multicolumn{2}{c}{ Analytical HPLC $^{1}$} & \multicolumn{2}{c}{$\mathrm{m} / z$} \\
\cline { 2 - 5 } & Retention time (min) & Gradient $(\%)$ & Calcd & Found \\
\hline $\mathbf{5}$ & 21.3 & $5-45$ & $1027.2[\mathrm{M}+3 \mathrm{H}]^{3+}$ & 1026.9 \\
$\mathbf{9}$ & 24.9 & $5-45$ & $914.4[\mathrm{M}+3 \mathrm{H}]^{3+}$ & 914.5 \\
$\mathbf{1 0}$ & 21.0 & $5-45$ & $849.4[\mathrm{M}+3 \mathrm{H}]^{3+}$ & 849.6 \\
$\mathbf{1 1}$ & 21.9 & $5-45$ & $1027.8[\mathrm{M}+3 \mathrm{H}]^{3+}$ & 1027.8 \\
\hline
\end{tabular}

${ }^{1}$ Cosmosil 5C 18 -AR-II analytical column was employed.

(A)

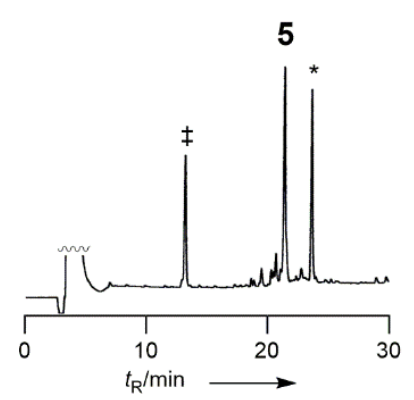

(B)

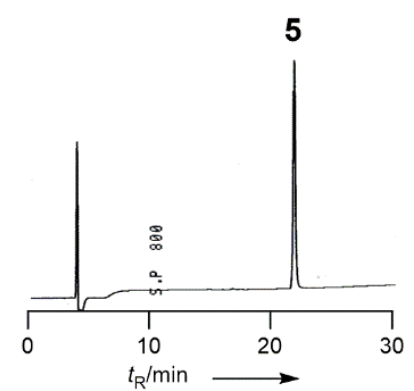

(C)

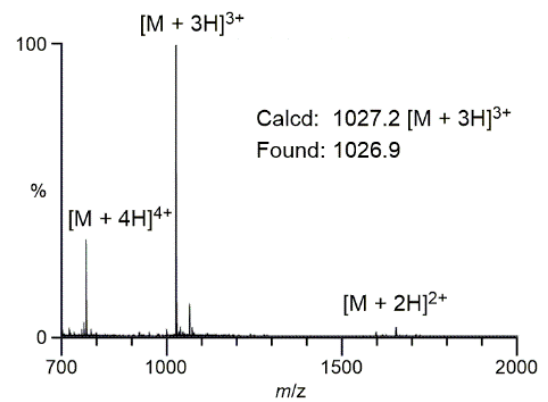

Figure S1. HPLC analysis of (A) crude materials after oxidative folding, (B) purified hANP 5. (C) Mass spectrum of purified hANP 5. ${ }^{*}$ Released SEAlide unit. *Nonpeptidic compounds probably derived from photoremoval of the NV unit. 
Scheme S5. Synthetic flow chart for the reduced form SNX-482 using N-to-C directed sequential NCL.
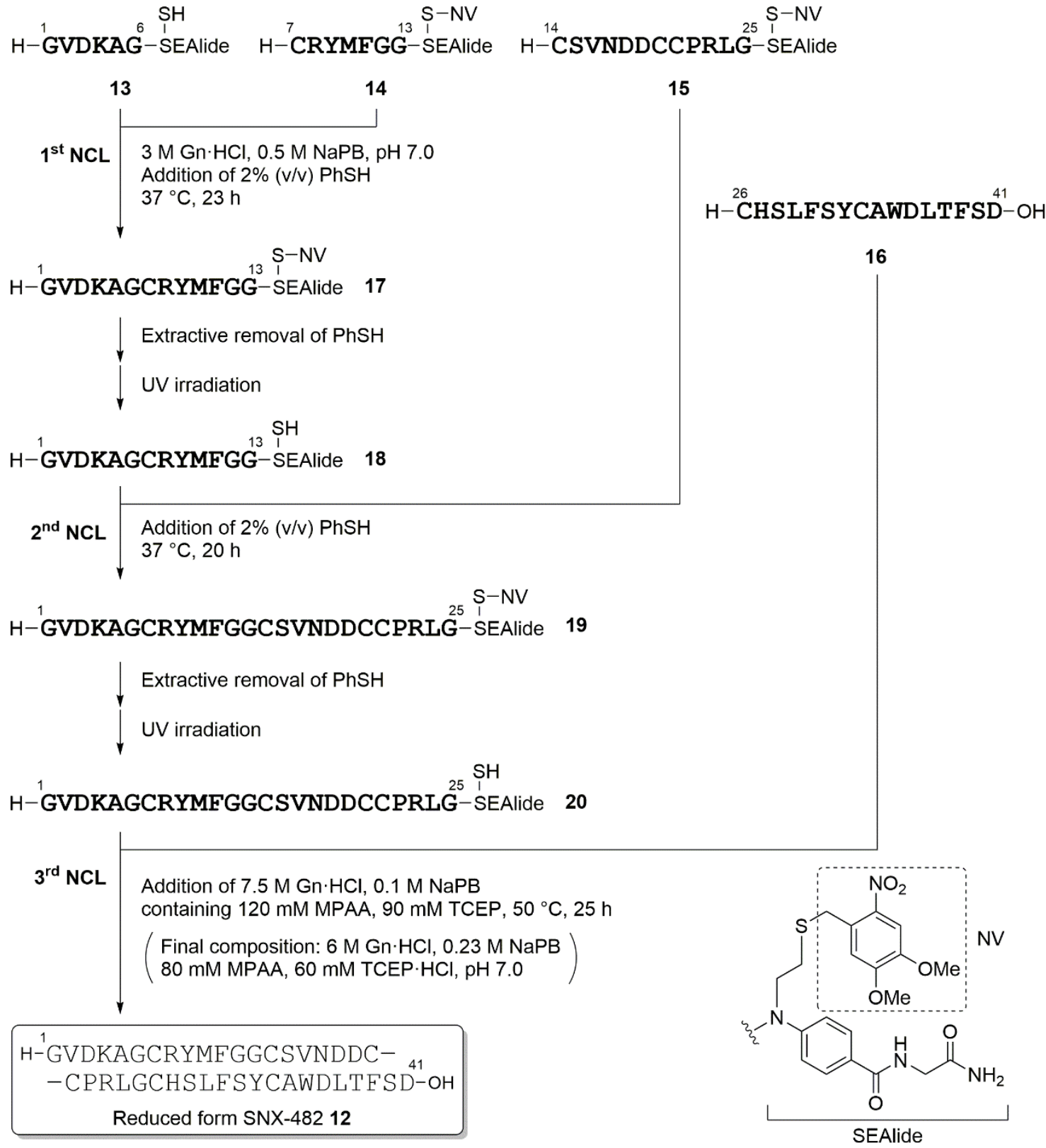

Synthesis of Reduced Form SNX-482 Using N-to-C Sequential NCL.

Peptide $13(2.25 \mathrm{mg}, 2.00 \mu \mathrm{mol})$ and peptide $14(3.21 \mathrm{mg}, 2.00 \mu \mathrm{mol})$ were dissolved in $3 \mathrm{M} \mathrm{Gn} \cdot \mathrm{HCl}-0.5$ M NaPB (pH 7.0, $2 \mathrm{~mL})$, and 2\% (v/v) PhSH was added to the obained mixture. This solution was 
incubated at $37{ }^{\circ} \mathrm{C}$ and the reaction was completed within $23 \mathrm{~h}$. An NV group on ligated product 17 was cleaved according to the general method to give 18. To the reaction mixture, $2 \%(\mathrm{v} / \mathrm{v}) \mathrm{PhSH}$ and peptide 15 were added and the resulting solution was incubated at $37^{\circ} \mathrm{C}$. After $20 \mathrm{~h}$, the reaction was completed and afforded ligated peptide 19. UV irradiation for the removal of an NV group on ligated product 19 were performed in the same manner and afforded peptide 20. This solution was diluted with $4.00 \mathrm{~mL}$ of 7.5 M Gn·HCl-0.1 M NaPB containing $120 \mathrm{mM}$ 4-mercaptophenylacetic acid (MPAA), $90 \mathrm{mM}$ tris (2-carboxyethyl)phosphine $\cdot \mathrm{HCl}(\mathrm{TCEP} \cdot \mathrm{HCl}$ ) (final $\mathrm{pH}$ 7.0). Then, peptide 16 was added to this solution and the resulting mixture was incubated at $50{ }^{\circ} \mathrm{C}$ for $25 \mathrm{~h}$. The obtained mixture was purified by analytical HPLC (Cosmosil Protein-R analytical column with a linear gradient of solvent B in solvent A over 30 min: $15-50 \%)$ to afford reduced form SNX-482 $\mathbf{1 2}$ as a white lyophilized powder (2.37 mg, $0.478 \mu \mathrm{mol}, 24 \%)$. Characterization data of peptides are shown in Table S3.

\section{Scheme S6. Synthetic flow chart for the reduced form SNX-482 in a convergent route.}

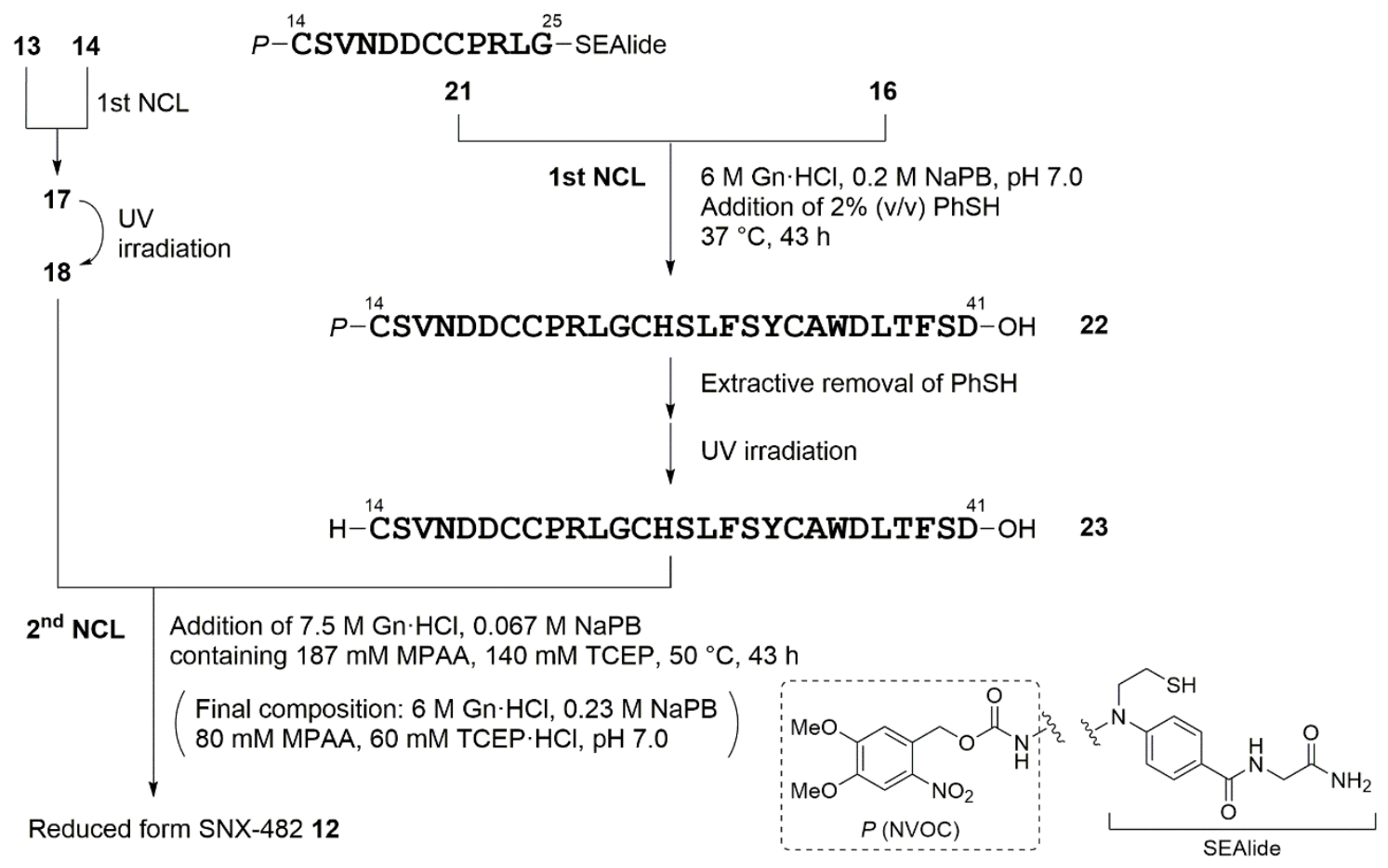

\section{Convergent Synthesis of Reduced Form SNX-482.}

A solution of peptide fragment $\mathbf{1 8}$ was prepared in the same manner as described above. A ligation between peptide $16(4.47 \mathrm{mg}, 2.00 \mu \mathrm{mol})$ and NVOC-protected fragment 21 (3.97 mg, $2.00 \mu \mathrm{mol})$ was performed in $3 \mathrm{M} \mathrm{Gn} \cdot \mathrm{HCl}-0.5 \mathrm{M} \mathrm{NaPB}(\mathrm{pH} 7.0,2 \mathrm{~mL})$ and gave ligated peptide 22. An NVOC group was cleaved under the same conditions for the deprotection of an NV group to give peptide $\mathbf{2 3}$. These 
resulting solutions were combined and the obtained mixture was diluted with $3.00 \mathrm{~mL}$ of $7.5 \mathrm{M} \mathrm{Gn} \cdot \mathrm{HCl}-$ $67 \mathrm{mM}$ NaPB containing $187 \mathrm{mM}$ MPAA and $140 \mathrm{mM}$ TCEP. $\mathrm{HCl}$ (final $\mathrm{pH}$ 7.0). After incubation at $50{ }^{\circ} \mathrm{C}$ for $25 \mathrm{~h}$, the reaction mixture was purified under the same conditions as mentioned above to afford reduced form SNX-482 12 as a white lyophilized powder (2.92 mg, $0.589 \mu \mathrm{mol}, 30 \%)$. Characterization data of peptides are shown in Table S3.

Table S3. Characterization data of peptides for the synthesis of SNX-482.

\begin{tabular}{cccccc}
\hline \multirow{2}{*}{ Peptide } & \multicolumn{4}{c}{ Analytical HPLC } & \multicolumn{2}{c}{$\mathrm{m} / z$} \\
\cline { 2 - 6 } & Column $^{1}$ & Retention time (min) & Gradient $(\%)^{2}$ & Calcd & Found \\
\hline $\mathbf{1 2}$ & A & 23.5 & $10-60$ & $1500.3[\mathrm{M}+3 \mathrm{H}]^{3+}$ & 1500.4 \\
$\mathbf{1 7}$ & B & 21.2 & $10-55$ & $895.9[\mathrm{M}+3 \mathrm{H}]^{3+}$ & 895.6 \\
$\mathbf{1 8}$ & B & 17.0 & $10-55$ & $798.4[\mathrm{M}+3 \mathrm{H}]^{3+}$ & 798.2 \\
$\mathbf{1 9}$ & B & 21.6 & $10-55$ & $1018.4[\mathrm{M}+3 \mathrm{H}]^{3+}$ & 1018.2 \\
$\mathbf{2 0}$ & B & 18.6 & $10-55$ & $953.4[\mathrm{M}+3 \mathrm{H}]^{3+}$ & 953.2 \\
$\mathbf{2 2}$ & B & 27.3 & $10-55$ & $1132.8[\mathrm{M}+3 \mathrm{H}]^{3+}$ & 1132.7 \\
$\mathbf{2 3}$ & B & 23.9 & $10-55$ & $1053.1[\mathrm{M}+3 \mathrm{H}]^{3+}$ & 1052.7 \\
\hline
\end{tabular}

${ }^{1}$ Column A: Cosmosil Protein-R analytical column was employed. Column B: Cosmosil 5C 18 -AR-II analytical column was employed.

(A)

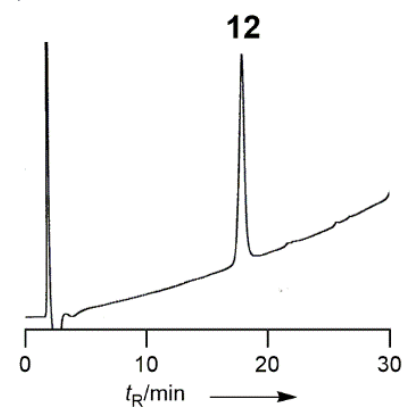

(B)

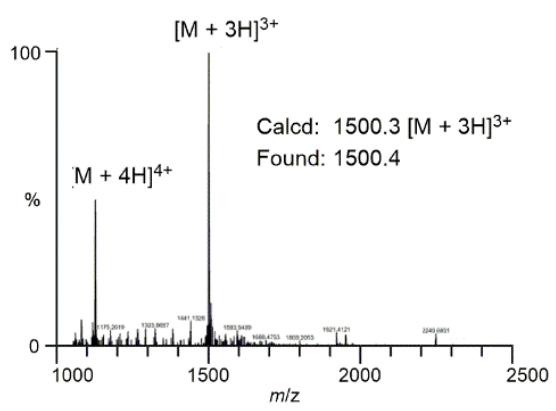

Figure S2. (A) HPLC analysis of purified reduced form SNX-482 12. TSKgel Octadecyl-2PW analytical column was employed. (B) Mass spectrum of purified reduced form SNX-482 12. 
${ }^{1} \mathrm{H}$ NMR spectrum of 3

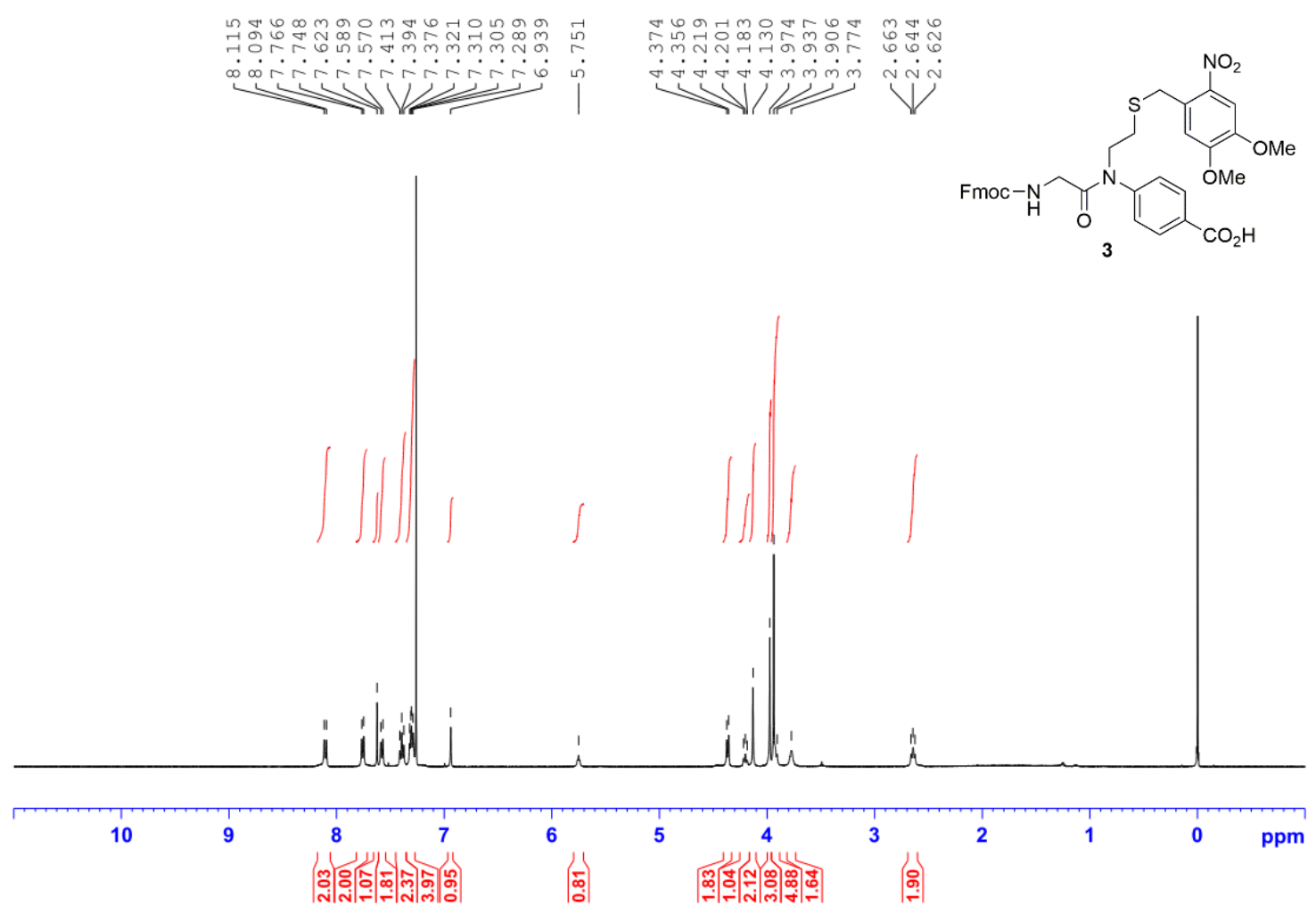

${ }^{13} \mathrm{C}$ NMR spectrum of 3

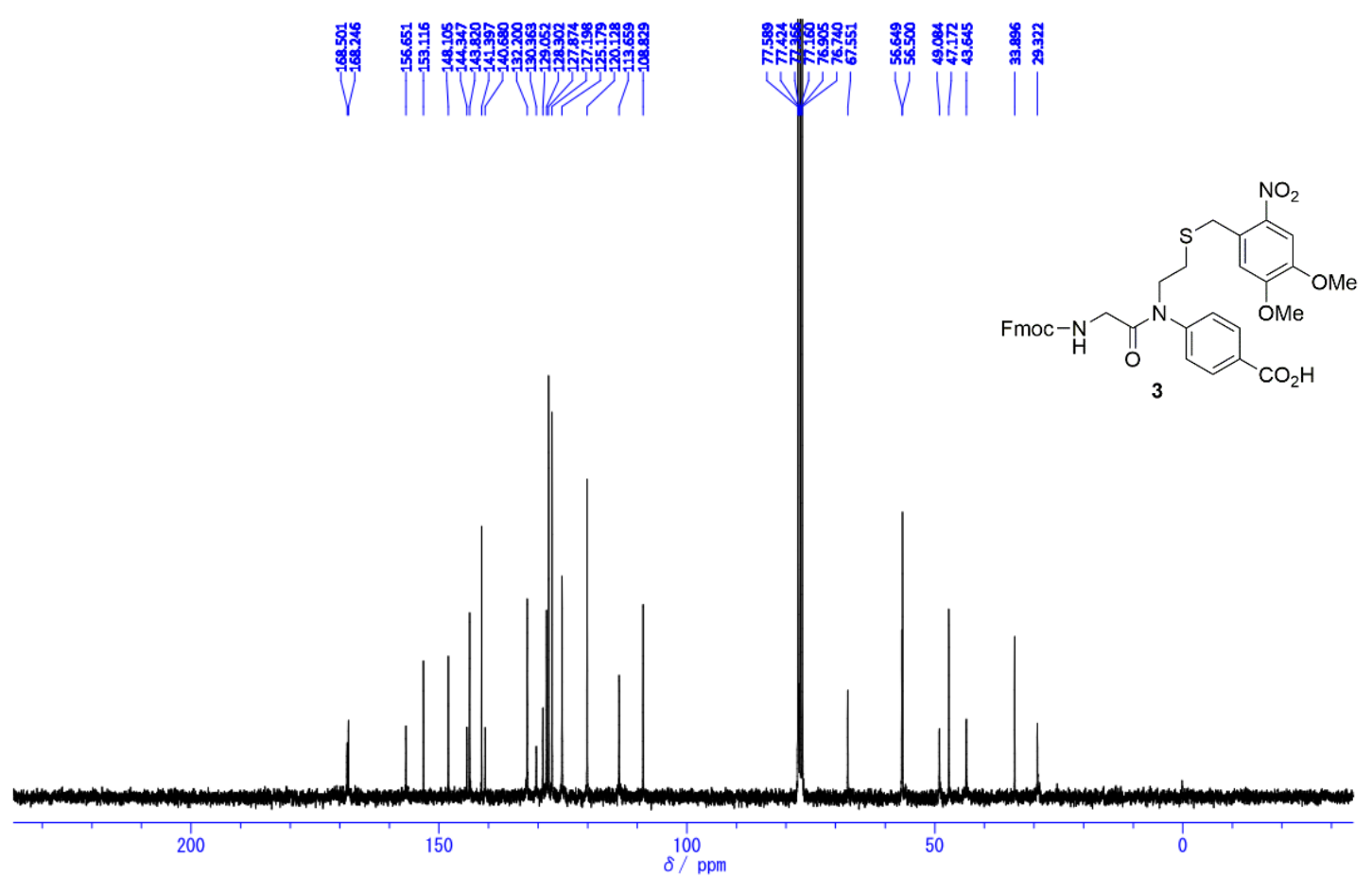




\section{References}

S1. Yoshiya, T.; Taniguchi, A.; Sohma, Y.; Fukao, F.; Nakamura, S.; Abe, N.; Ito, N.; Skwarczynski, M.; Kimura, T.; Hayashi, Y.; Kiso, Y. Org. Biomol. Chem. 2007, 5, 1720.

S2. Fomina, N.; McFearin, C.; Sermsakdi, M.; Edigin, O.; Almutairi, A. J. Am. Chem. Soc. 2010, 132, 9540. 